\title{
nature
}

13 January 2005 Volume 433 Issue no 7022

\section{Dangerous state of denial}

Despite the warning shots of SARS and last year's Asian outbreak of avian flu, governments are still not doing enough to monitor and prepare for the next viral pandemic. This inaction is scandalous.

$\mathrm{F}$ or Mrs Luat, the H5N1 avian flu virus could bring economic ruin. Three years ago, she and her husband borrowed US\$12,500 to establish a small chicken farm in Hay Tay province, near the Vietnamese capital Hanoi. They raise 6,000 chickens at a time in their single shed, selling the entire stock every couple of months to a Thai company that distributes the meat within Vietnam. But last year, their shed lay empty for six months after H5N1 flu hit neighbouring farms. Mrs Luat estimates the couple's losses at $\$ 1,500$. If it happens again, they may be unable to service their debts.

While smallholders such as the Luats face the most immediate threat, the continuing presence of the H5N1 virus in Vietnam and neighbouring countries could spell a global disaster, in both economic and humanitarian terms. H5N1 is deadly to both chickens and people, but thankfully isn't easily transmitted from person to person. But if it exchanges genes with a mammalian flu virus, H5N1 could become a mass killer that would rapidly sweep the globe. If that happens, tens of millions of people could perish.

Since H5N1 starting spreading through Asian poultry flocks in 2003, the World Health Organization (WHO) has been sounding the pandemic alarm. Two main actions are required. First, surveillance for human and animal flu viruses in affected countries needs to be stepped up, to provide an early warning of the emergence of a possible pandemic strain. Second, nations around the world must develop plans to protect their populations should this occur. This will require stringent quarantine procedures, plus the rapid deployment of vaccines and antiviral drugs.

Surveillance in Asia leaves much to be desired. In Vietnam, where at least 22 people have already died, officials lack the resources to conduct the extensive serological studies that are needed to investigate the full extent of human infection (see page 102). Neighbouring Laos and Cambodia, meanwhile, have virtually no monitoring capacity.
The WHO has appointed an official in Geneva to coordinate Asian research efforts, and has enlisted the help of the US National Institute of Allergy and Infectious Diseases to establish a regional clinical research network. But much more needs to be done.

On the veterinary side, the picture is even bleaker. Rich governments are disinclined to build up poor countries' ability to keep track of animal viruses, seeing this as economic assistance rather than humanitarian aid. The experience of smallholders like Luat shows that surveillance for such viruses has vast local economic significance. But rich countries must abandon their mindset of protectionism and realize that establishing global surveillance will ultimately help protect the health and economic productivity of their own citizens.

The lack of assistance with surveillance is hardly surprising, however, when you consider that few rich nations have made any effort to stockpile Tamiflu, the one drug that can combat a flu virus as pathogenic as $\mathrm{H} 5 \mathrm{~N} 1$, nor to ramp up capacity to produce large quantities of a new vaccine should a pandemic strain emerge. On 8 December, the WHO summarized the situation: "While it is impossible to accurately forecast the magnitude of the next pandemic, we do know that much of the world is unprepared for a pandemic of any size."

The world dodged a bullet in 2003, when a newly emerging coronavirus sparked an outbreak of severe acute respiratory syndrome, or SARS. We may yet avoid $\mathrm{H} 5 \mathrm{~N} 1$ flu, but sooner or later we will face a new global viral pandemic, probably triggered by a chance encounter between a mammalian flu virus and an avian one, such as H5N1. When that happens, and the corpses start piling up, world leaders will be asked some searching questions about the steps they took to avoid such a calamity and to prepare for the worst.

After the SARS outbreak, Nature took stock of our preparedness for the next viral threat (see Nature 424,113;2003) and asked what we have learned. The answer so far, it seems, is not very much.

\section{Rockets in Russia's back yard}

\section{Users of the Baikonur rocket base should care more about the health of local people.}

$D$ icture this scenario. A rocket lifts off, carrying a cargo destined for Earth orbit. As the rocket heads upwards, it dumps highly toxic fuel onto the land below it. People living below the flight path say the pollution is making them ill, and demand compensation.

In Europe or the United States, this would be headline news. We would expect NASA or the European Space Agency (ESA) to investigate. And should the allegations of ill-health prove correct, national governments would be forced to pay compensation.

For US and European residents, this problem is hypothetical. For the Siberian people who live north of the Baikonur Cosmodrome in Kazakhstan, it isn't (see page 95). Both ESA and NASA use Baikonur, but neither they nor the Russian administrators of the base seem overly concerned about the population.

The first detailed epidemiological study of people living under the flight path suggests that the rocket fuel is indeed causing health problems. The study has not been peer reviewed, but it is funded by a respected organization. At the very least, it should serve as a warning flag to any agency that uses the base.

Rosaviakosmos, the Russian space agency, says its own studies show that the launches do not cause ill health. But the satellite launching business is highly profitable, so the agency has a clear conflict of interest. ESA and NASA do not run the base but share some responsibility for how it is used. There is a recent analogy here with Western companies who are rightly under pressure to clean up their act in nations where employment law does little to protect workers.

There are currently insufficient data for firm conclusions to be drawn, so Rosaviakosmos should fund a detailed independent investigation, and ESA and NASA should offer to help. All three should commit to making the results publicly available as soon as possible.

If the Western agencies wonder why they need be involved, they should ask themselves what would happen if US or European residents made similar complaints to those emanating from Siberia. 